\title{
A Principled Pragmatic Approach to Teaching Foreign Language Grammar at Tertiary Schools
}

\author{
O. B. Tarnopolsky, O. V. Monastyrna, P. W. Bradbeer
}

\author{
Alfred Nobel University, Dnipro, Ukraine \\ Corresponding author. E-mail: otarnopolsky@ukr.net
}

Paper received 15.10.18; Accepted for publication 22.10.18.

\begin{abstract}
https://doi.org/10.31174/SEND-PP2018-180VI74-14
\end{abstract}
\begin{abstract}
The article discusses the issue of improving the efficiency of developing tertiary students' grammar skills in foreign language courses taught at institutions of higher learning. It is argued that this efficiency is believed to be achieved through introducing B. Kumaravadivelu's principled pragmatic approach. Such an approach is implemented by way of rationally combining the elements from different, often mutually contradictory, methods from the stock of those that have been developed in the history of foreign language teaching. The practice of using just such an approach at different stages of working on the new grammar material in foreign language classes at higher schools is analyzed.
\end{abstract}

Keywords: tertiary schools, foreign language teaching, teaching grammar, principled pragmatism.

Introduction. Teaching foreign language grammar (including teaching it to students in tertiary education) traditionally remains a controversial issue. From totally denying the necessity of teaching grammar and even not recognizing its existence [7] to stating the necessity of teaching grammar only implicitly and denying the rationality of explicit form-focused instruction [5], to recognizing the obligatory nature of such form-focusing but emphasizing the requirement of training grammatical structures only in communication-oriented learning activities [2], to admitting the possibility of combining those activities with form-focused non-communicative exercises [3] and even to traditional approaches where the exercises of the latter type dominate - such is the range of different views on the issue under discussion. The time has come to try and combine those different and often opposing approaches, extracting from each of them what can be efficiently used for a given group of students in the given conditions of their teaching and learning with the given goals of such teaching and learning. This combination can be achieved on the basis of B. Kumaravadivelu's principled pragmatism [6]. The author claims that we are now living in the post-method era and there can be no single method or approach to teaching foreign languages which is good for all conditions. Teachers themselves should select from all the methods developed during all the history of their development those that, regardless of their theoretical foundations, are (or, at least, seem to be) the best suited to their particular conditions of teaching and learning, the particular teaching/learning goals, and the particular group of students. This is what is called pragmatism. But such pragmatism must be principled, i.e. (according to B. Kumaradivelu [6]) provide for: 1) maximizing learning opportunities; 2) minimizing perceptual mismatches; 3) facilitating negotiated interaction; 4) promoting learner autonomy; 5) fostering language awareness; 6) activating intuitive heuristics; 7) contextualizing linguistic input; 8) integrating language skills; 9) ensuring social relevance, and 10) raising cultural consciousness. That entails the absolute requirement that everything selected by the teacher from different teaching/learning methods cannot be in conflict with any of the principles listed above.

What is written in this article is an attempt to substantiate and implement the outlined principled pragmatic approach in teaching foreign language grammar in foreign language courses at tertiary schools so as to try and finally solve the controversy mentioned at the beginning of the preceding paragraph, at least, in what concerns foreign language instruction in higher education.

The review of publications on the topic of the article. The most traditional and well known approach to teaching grammar (at whatever educational institutions) includes the stages of: 1) the teacher giving examples of some new grammatical structure in the text being read or listened to by the students; 2) explicit explanation of that structure to students by the teacher who formulates the rule; 3) the students doing a number of noncommunicative form-focused exercises with the aim of making the use of the grammatical structure being learned automatic and subconscious; 4) trying to transfer the skill of automatically and subconsciously using that grammatical structure into communication (communicative learning activities) [1]. This approach has always been unsuccessful because the transfer of skills developed in formfocused exercises into communication hardly ever occurs since the gap between the two types of activities is too broad - all the more so since the communicative learning activities are insufficiently used in the approach under consideration.

As the reaction to the failure of the approach discussed above to ensure the development of students' genuinely communicative grammar skills, the following approach was based on elimination of non-communicative formfocused exercises, replacing them with communicationoriented or provisionally communicative exercises [2]. They were also based on numerous repetitions of one and the same grammatical structure (to achieve its automatic use) but in the conditions that imitated the basic parameters of human communication, such as the communicative intention and communicative situation, which provided for the transfer of the developed skills into communicative learning activities and genuine target language communication. The disadvantage of that approach was found in students' grammar skills, which though being quite adapted to genuine communication, yet falling short in accuracy in comparison with the first approach.

One of the Western approaches called the "Lexical Approach" [7] totally denied the necessity of teaching grammar, not even recognizing its actual existence but reiterating that any language is the systematized assort- 
ment of "lexical chunks" and that language instruction should give students opportunities of acquiring those "chunks" without trying to learn the grammatical structures underlying them.

This approach has never been broadly recognized and applied in teaching practice, but much broader recognition and practical application has been gained by the approach which admits the necessity of forming learners' grammar skills but only implicitly, through abundant "comprehensible input" in the target language to which students are constantly exposed and from which they subconsciously acquire both the understanding of how that language functions grammatically and the relevant skills [5].

The latter approach was developed for teaching English as a second language, i.e. the target language that international students acquire while learning it in an English-speaking country, where they are permanently and totally "immersed" in the comprehensible input delivered to them in that language. But even when considering language training in such conditions, some authors do not agree with the idea of only implicit (subconscious) grammar skill acquisition [8]. They emphasize the necessity of learners' consciousness-raising as to the grammatical structure of the language by way of giving students opportunities of having their attention focused on new grammatical structures and deducing, under the guidance of the teacher, their meanings and formal characteristics from numerous examples supplied to them.

In the conditions of foreign language teaching and learning, such as exist at Ukrainian tertiary schools, the idea of learners' totally implicit (subconscious) grammar skill acquisition seems to be utterly preposterous since a sufficient amount of comprehensible input required for subconscious acquisition not only cannot be ensured but cannot even be closely approached. Therefore, the choice remains to be made only between the first and the second approaches indicated above, though some authors suggest that a certain combination of them is possible by way of introducing into the second approach a limited number of non-communicative form-focused exercises for improving the learners' grammatical accuracy in communication [3]. Such an introduction should be limited indeed, so as not to compromise in any way the absolute dominance of communication-oriented or provisionally communicative grammar exercises used within the framework of the approach. However, even that combination has not led to achieving the level of development of learners' grammar skills that would make those skills completely communicative, on the one hand, and sufficiently grammatically accurate, on the other.

We believe that the solution can be found in uniting the elements not from only two but from all the five existing methodological approaches discussed above by way of following B. Kumaravadivelu's principled pragmatic approach [6] in the manner discussed below.

The aim of this article is to discuss the practical ways of achieving the principled and pragmatic unification of the elements from the five mentioned approaches into one single and harmonized pragmatic approach to teaching foreign language (English) grammar to tertiary students in Ukraine.

The methods and materials used by us were:
Methods: analysis of relevant professional literature; theoretical development of the principled pragmatic approach to teaching students grammar skills; practical development of the approach by way of elaborating the coursebooks for teaching English for professional purposes which practically embody the theoretically substantiated approach; introducing the four developed coursebooks into the teaching/learning process in university courses of English; observing the practical teaching/learning process based on the developed coursebooks to watch for the improvement or lack of improvement of students' grammar skills; analyzing the results and the coursebooks in question in terms of the extent of their correspondence to the ten principles of principled pragmatism formulated by B. Kumaravadivelu [6].

Materials: relevant professional literature and the four developed coursebooks for teaching English for professional purposes. The coursebooks were designed: for future economists and businesspeople; psychologists; pedagogues, and managers of the tourism and hospitality industry.

Results and their discussion. The approach to teaching grammar skills was based on dividing all the grammatical structures to be taught into three major categories:

1. Grammatical structures that do not need to be taught as grammar but rather as lexical chunks (see the third of the five approaches discussed above) by making students memorize them involuntarily through constant repetition in speech reception and speech production within the framework of communicative learning activities in reading, listening, speaking, and writing. When teaching English at tertiary schools, such structures may include structures with "let", irregular forms of adjectives and adverbs (good-better-the best, far-further-the furthest), a number of participial structures, and others.

2. Grammartical structures that may be taught only implicitly but not explicitly (see the fourth of the approaches cited in the Review of publications). This is achieved by making students frequently encounter relevant grammatical structures when reading and listening in the target language, so that gradually, but promptly enough, learners subconsciously realize the meanings and formal characteristics of such structures and, equally subconsciously, start using them in their own speech production as the result of their repeated perceptions of the written and oral utterances of others. A good example is the Past Continuous Tense in English. If students have learned the Present Continuous Tense well and have developed effective skills of freely using this tense in their own speech and understanding it in the speech of others, the Past Continuous Tense may be quite easily implicitly acquired through frequent exposures.

3. Grammartical structures that need explicit learning activities for their acquisition by Ukrainian students (like the Present Continuous Tense or regular forms of English adjectives and adverbs degrees of comparison). For such grammatical structures the developed approach foresees a four-stage procedure of organizing teaching and learning.

The four stages of that procedure include:

1. Presentation involving the focus of learners' attention on the meanings and forms of grammatical structures being learned; 
2. Developing the skills of using and understanding the grammatical structures being learned in oral speech -with learners' attention being focused on those structures;

3. Transferring those skills into written speech to be fluently used and understood there - again, with learners' attention being focused on the grammatical structures being learned;

4. Improving and completing the development of such skills in speaking, listening, reading, and writing without any focusing of learners' attention on grammatical structures.

Presentation. This stage begins with the demonstration by the teacher of the grammatical structure to be learned by the students and continues towards helping them understand its meaning and formal characteristics. Demonstration is implemented in communicative contexts only when students read or listen to coherent and cohesive meaningful texts where the grammatical structure in question is encountered a number of times (other methods of communication-oriented demonstrations are possible like using for it video materials, pictures, showing and commenting on actions being done, etc.). During and after the process of demonstration, the students' attention is focused on the grammatical structure to be learned and, under the guidance of the teacher, they try to guess its meaning and formal characteristics through the examples of use. In this way, the consciousness-raising procedure as advocated by the fourth approach discussed in the Review of publications is implemented. However, if that procedure fails (the students do not manage to understand the grammatical structure by way of deducing for themselves its meaningful and formal characteristics from numerous examples), the teacher gives the learners explicit explanations and formulates the grammar rule for them. Thus, the elements of the first, most traditional, approach cited in the Review of publications can be used in combination with the consciousness-raising approach.

Developing learners' skills of using and understanding the grammatical structures being learned in oral speech. This stage starts with students orally doing one or two non-communicative grammar exercises such as changing the tense of the verb-predicate or transforming sentences from the affirmative into the interrogative form, etc. The necessity of introducing a very limited number of such non-communicative exercises immediately after learners realize the meaningful and formal characteristics of the grammatical structure being learned was proved by a special experimental study where it was shown that this ensures the prophylaxis of grammar mistakes in further target language communication [4]. The shortest possible period of non-communicative learning activities is followed by a long period of training the grammatical structure through numerous oral repetitions of it in communication-oriented or provisionally communicative exercises that imitate in oral speech the basic parameters of human communication, such as communicative intentions and communicative situations. An example of such an exercise done with the help of a computer or an audio device can be as follows (the grammatical structure being trained is Past Simple question forms):

The instruction to students: Your provisional interlocutor-the speaker will be telling you how he spent his last summer vacation at the seaside in Odessa. Since you also plan to go there for your vacation, in the pauses after his statements ask him questions using the prompts given to you.

Speaker: Last summer I spent my holidays at the seaside in Odessa.

The prompt for students: When?

The expected students' question: When did you spend your vacation there?

The speaker's answer: In July. I spent two weeks there.

The prompt for students: to stay at a sanatorium or to rent a room?

The expected students' question: Did you stay at a sanatorium or did you rent a room?

Speaker: I rented a room, etc.

Such an exercise is a clear-cut case of training grammar skills in the conditions imitating some basic parameters of communication so as to make it easy to transfer such skills into genuine communication.

In general, at this stage the combination of three approaches discussed in the Review of publications can be observed: the first, the second, and the fifth.

The combination of those three approaches continues into the third stage of work on grammar materials - the stage of transferring the grammar skills under development into the written speech to be fluently used and understood there. In principle, at this stage the same two types of exercises are used as at the preceding stage (noncommunicative and provisionally communicative ones) with the difference that they are all done in writing for achieving the required transfer. Another difference lies in the broader use of non-communicative exercises, especially in students' out-of-class work, because, when done in writing, such exercises contribute much to reinforcing the grammar skills already developed at the preceding stage but needing further reinforcement.

The last stage, improving and completing the development of grammar skills in speaking, listening, reading, and writing, is not, in fact, teaching grammar. It is teaching speaking, listening, reading, and writing skills in purely communicative learning activities. But when doing such activities, students subconsciously and involuntarily not only reinforce but also improve and complete the development of grammar skills formed at the preceding stages. Here we return to the implicit grammar learning advocated by the followers of the third approach outlined in the Review of publications.

In this way, the approach suggested by us combines and harmonizes the elements from all the five existing approaches. That this harmony has really been achieved is demonstrated by two of its manifestations. The first is that the practical experience of using the developed coursebooks (see above) in classes of English at Alfred Nobel University in Dnipro, Ukraine, has clearly demonstrated the considerable improvement of students' grammar skills, in comparison with the more traditional ways of learning grammar, and the greater facility of students for acquiring those skills. Certainly, this statement can be considered only as a preliminary one because there remains an absolute requirement that it should be proved in a special experimental study. But until such a study is organized, even the manifestations of the indicated advantages in the practical teaching/learning process as 
observed by practical teachers are a testimony of the benefits of the suggested pragmatic approach.

The second manifestation is more substantial since even from the given description of the suggested approach it can be seen how well it matches B. Kumaravadivelu's [6] ten principles underlying practical introduction of principled pragmatism into any aspect of foreign language teaching and learning. Those principles, listed in the Introduction to this article, first include maximizing learning opportunities which the suggested approach definitely achieves due to the fact that it presupposes a very broad range of ways of learning grammar. The same concerns the principle of minimizing perceptual mismatches (the second principle). Such mismatches mean the discrepancies between the teacher's intentions and the student's interpretations of those intentions, so that those discrepancies can cause the learning outcomes unexpected and undesirable for both sides. The discrepancies in question are hardly possible when using our approach because: 1) the students are to a great extent autonomous in working on new grammar materials (cf. B. Kumaravadivelu's fourth principle of promoting learner autonomy [6]) and the teacher plays the role of a facilitator, e.g. explaining some grammar rule explicitly only if learners fail to deduce it themselves at the presentation stage. They are autonomous at the exercising stages too, and this approach also envisages learners' interaction among themselves both when exercising and when trying to deduce the meanings and formal characteristics of new grammatical structures from the meaningful contexts in which they are demonstrated at the presentation stage (the principle of facilitating negotiated interaction). Moreover, such meaningful contexts used at the presentation and exercising stages (when doing communication-oriented and purely communicative learning activities) not only contextualize the linguistic input (the seventh of B. Kumaravadivelu's principles [6]). If the context is taken from the target culture and social life, as it should be, the principles of ensuring social relevance and raising cultural consciousness are implemented. The fact that learners mostly autonomously try and achieve understanding and their own consciousness-raising in what concerns the meanings and forms of new grammatical structures activates their intuitive heuristics and fosters language awareness (the fifth and the sixth of B. Kumaravadivelu's principles [6]). Finally, the transition from oral training of grammar material to its training in written exercises and other written learning activities contributes to integrating language skills (the eighth principle).

Thus, it can be safely asserted that the suggested approach is a good example of and fully lies within the domain of the principled pragmatism paradigm.

Conclusion. What is said in this article demonstrates the possibility of introducing B. Kumaravadivelu's principled pragmatic approach into teaching even separate aspects (grammar in our case) of a given foreign language in courses of that language at tertiary schools. The principled pragmatism in such instruction is achieved through harmoniously combining elements from different approaches developed in foreign language teaching theory and practice to create a new single approach uniting the advantages of those approaches from which separate elements have been borrowed. The harmony of such unification can be attained by strictly adapting the functioning of the new unified approach to the ten principles that constitute the essence of the principled pragmatism. The preliminary practical success of the approach suggested in the article (this success is still in need of being doublechecked in a special experimental study) gives grounds to hope that all foreign language teaching at tertiary schools can be reconstructed on the basis of the principled pragmatism, thus uniting the advantages of all the existing approaches, which often seem to oppose one another, and eliminating that opposition by welding them into a harmonious unity.

\section{REFERENCES}

1. Общая методика обучения иностранным языкам в средней школе / Под ред. А.А. Миролюбова, И.В. Рахманова, В.С. Цетлин. Москва: Просвещение, 1967.

2. Пассов Е.И. Коммуникативный метод обучения иноязычному говорению. Москва: Просвещение, 1985.

3. Скляренко Н.К. Сучасні вимоги до вправ для формування іншомовних мовленнєвих навичок та вмінь // Іноземні мови, 1999. №3, С. 3-7.

4. Тарнопольский О.Б. Профилактика грамматических ошибок в экспрессивной устной речи // Иностранные языки в высшей школе. Москва: Высшая школа, 1987. Вып. 20. С. 72-79.

5. Krashen, S.D. Principles and Practice in Second Language Acquisition. London: Prentice-Hall International (UK) Ltd., 1981.

6. Kumaravadivelu, B. Beyond Methods: Macrostrategies in Language Teaching. New Haven and London: Yale University Press, 2003.

7. Lewis, M. The Lexical Approach. The State of ELT and a Way Forward. Hove: Language Teaching Publication, 1996.

8. Rutherford, W.E. Second Language Grammar Learning and Teaching. London and New York: Longman, 1987.

\section{REFERENCES}

1. The General Methodology of Foreign Language Teaching at Secondary Schools / Ed. by A.A. Mirolyubov, I.V. Rakhmanov, V.S. Tsetlin. Moscow: Prosvescheniye, 1967.

2. Passov, E.I. The Communicative Method of Teaching Foreign Language Speaking. Moscow: Prosvescheniye, 1985.

3. Sklyarenko, N.K. Contemporary requirements to exercises for developing foreign language skills // Inozemny Movy, 1999. No.3, P. 3-7.

4. Tarnopolsky, O.B. Prophylaxis of grammar mistakes in expressive oral speech // Inostrannye Yaziki v Vysshey Shkole. Moscow: Vysshaya Shkola, 1987. Is. 20. P. 72-79.

5. Krashen, S.D. Principles and Practice in Second Language Acquisition. London: Prentice-Hall International (UK) Ltd., 1981.

6. Kumaravadivelu, B. Beyond Methods: Macrostrategies in Language Teaching. New Haven and London: Yale University Press, 2003.

7. Lewis, M. The Lexical Approach. The State of ELT and a Way Forward. Hove: Language Teaching Publication, 1996.

8. Rutherford, W.E. Second Language Grammar Learning and Teaching. London and New York: Longman, 1987. 